\title{
Digital transformation to support literacy teaching to deaf Children: From storytelling to digital interactive storytelling
}

\author{
Leandro Flórez-Aristizábal ${ }^{\mathrm{a}, \mathrm{c},}$, Sandra Cano ${ }^{\mathrm{b}}$, César A. Collazos ${ }^{\mathrm{c}}$, \\ Fernando Benavides ${ }^{\mathrm{b}}$, Fernando Moreira ${ }^{\mathrm{d}, \mathrm{e}}$, Habib M. Fardoun ${ }^{\mathrm{f}}$ \\ ${ }^{a}$ Institución Universitaria Antonio José Camacho, GRINTIC Group, Cali, Colombia \\ ${ }^{\mathrm{b}}$ University of San Buenaventura, LIDIS Group, Cali, Colombia \\ ${ }^{\mathrm{c}}$ University of Cauca, Colombian, IDIS Group, Popayan, Colombia \\ ${ }^{d}$ Univ Portucalense, Portucalense Institute for Legal Research - IJP, Rua Dr. António Bernardino Almeida, 541-619, P 4200-072 Porto, Portugal \\ IEETA, Univ. Aveiro, Aveiro, Portugal \\ ${ }^{\mathrm{f}}$ Ahlia University, Bahrain, 999 Manama, Bahrain
}

\section{A R T I C LE IN F O}

Keywords:

Storytelling

Deaf children

Literacy

Collaborative learning

\begin{abstract}
A B S T R A C T
Currently, learning technologies are transforming and modifying educational systems with im-pressive progress of Information and Communication Technologies. Furthermore, when these technologies are available, accessible, usable and a $\square$ ordable, they represent more than just a transformation for people with disabilities, they represent real opportunities with access to an inclusive education and help to overcome the obstacles they meet in classical educational sys-tems. In this paper we present some experiences using technology to support literacy teaching for deaf children through a storytelling technique.
\end{abstract}

\section{Introduction}

The growth of technology is changing the way society communicates. The digital transformation is changing not only society but also education. According to a report given by Digital Vortex in 2015 (Bradley et al., 2015), education is the sector with more potential in the incorporation of technology in the world. A new interest arises; students may have an educational model adjusted according to their profile thanks to technology. Therefore, some educational strategies emerge, such as: transformation of pedago-gical processes, virtual learning environments, interactive educational applications, collaborative learning, among others.

In Latin America, there are still regions where the use of technologies is low. According to a report given by The Global Information Technology Report of 2016 (Baller et al., 2016), Colombia ranks 66th in Internet use, while Chile ranks 36th, Ecuador 82th and Peru 88th, which indicates that there is still more work to be done in order to close the gap between technology and education.

The role of Information and Communication Technologies (ICT) is to serve as a support tool to access knowledge. So, with the use of technological systems, students can learn from practice in a playful context. A document on strategic approaches on ICT in education in Latin America and the Caribbean published by the UNESCO in 2013, indicates that "ICT must go beyond issues of equipment availability and connectivity, it is necessary to move towards the issue of uses and their impacts on learning" (UNESCO, 2013). 
Digital transformation is changing the way classrooms should work. However, it does not mean that it is only the inclusion of technologies within the classrooms what is needed, it is knowing how to use these tools as a new educational resource. So it is necessary to refer to 4 concepts that are being applied in education: Internet of Things, cloud, social and mobile (Burd et al., 2017). Internet of Things (IoT) allows the connection of di $\square$ erent technologies and devices on the web, which allows access to information from anywhere (Oh et al., 2017). Cloud, where the student is given the tools to work in collaboration with other colleagues and the teacher, besides, the educational material is already in digital form, which facilitates the portability, storage and accessibility of this (Bazzaza and Salah, 2015). Social, with educational platforms and the management of networks that allow collaborative work (Social Computing Research Group, 2005). Finally, mobile, o $\square$ ering the teacher a more dynamic, interactive and playful type of material for the student, in addition to helping to collect data about the student and that can serve to improve the strategies in the teaching process (del Valderrama Bahamóndez and Schmidt, 2010).

The impact of technologies in the classroom for children has been very positive. A study conducted by UNICEF in 2017 (UNICEF, 2017 ) examines the ways in which digital technology has changed the lives of children and their opportunities. It also indicates how much time children spend using technologies, which they recommend should be moderate, since their non-use or too much use can have a negative impact. It also finds that they take more time using technology in the social field, to be in permanent contact with their friends or to make new ones. On the other hand, UNESCO remarks about the importance of ICTs to be included in the class-rooms, since it can enhance learning in di $\square$ erent types of contexts (Guttman, 2003). Therefore, with the growth of technology, many researchers and the private sector show an increase in designing interactive and innovative technology for children.

Technology in the classroom could create a major impact if it is designed to be accessible for children with disabilities, which could support teaching/learning processes that are usually adapted to the particular children's needs. An example of this processes is literacy teaching for deaf children, where strategies must di $\square$ er from those used with hearing children. One strategy that has been proved to be e $\square$ ective in teaching and learning processes is storytelling. Storytelling may a $\square$ ect positively di $\square$ erent aspects of chil-dren's life such as the development of skills in communication (Garzotto et al., 2010). In the field of education, storytelling has been proven to be a resource to work in di $\square$ erent areas of knowledge like natural sciences (Pérez Molina et al., 2013), foreign language teaching (Reyes Torres et al., 2012), sign language (Peix Cruz, 2014), programming (Burke and Kafai, 2010) and literacy (Moreno de León et al., 2016) (Flórez Aristizábal et al., 2017a).

Unfortunately, there is not enough support from technology in literacy teaching to deaf children due to a lack of guidelines or frameworks to guide developers or designers in the development of tools aimed at this community, basically, because they should be designed to support the specific strategies used by the teacher, instead, teachers must adapt their strategies to existing tools and sometimes this is just not possible because of di $\square$ erent factors such as the language used in the tool, the tool was designed to be used by hearing children. Two educational institutions (EI) are part of this study, La Pamba and the Institute of Special Therapy of Senses (ITES). These EI not just face the problems already mentioned, they also lack of monetary resources to acquire new technology, they usually depend on donations and the equipment they have right now, like computers, is rather old. This means that latest software applications will not run on these devices. In order to address these issues, this study is focused in supporting a storytelling strategy used in both institutions for literacy teaching to deaf children. Since the strategy used by the teachers is very particular to the needs of their students, we are going to provide a solution customized to their teaching process by making children and teachers part of the design lifecycle. Paper and digital prototypes were developed and adapted to be used with the current resources the institutions have.

\section{Background}

\subsection{Digital transformation and education}

Digital Transformation in schools is not about innovation or technology, it's more a matter of culture. By digitalizing the learning process, not only students but also teacher can improve their skills with the same purpose, which is to create a more engaging and e $\square$ ective education process. (Acer for Education, 2017). Unfortunately, there are many regions in Latin America that still do not have full access to technology and thus this digital transformation is lagging. Therefore, there is a technological inequality gap. Even so, teachers have taken a greater interest in including available and a $\square$ ordable technology as support material in the classroom. In turn, researchers and entrepreneurs have been involved in creating technologies related to: mobile education, Internet of Things, edu-cational social networks and education in the cloud. The massive increase of personal devices at home and schools arises important questions about its use and role in the learning process (Chiong and Shuler, 2010). The presence of these devices in the life of students allows to think about emergent educational alternatives with new technologies (Arias Ortiz and Cristia, 2014) and this potential is greater when technology is present in homes as well (Mascheroni and Ólafsson, 2014).

\subsection{Strategies for the development of literacy skills}

The development of literacy skills is one of the main challenges deaf children must face, since this is the way not just to com-municate with hearing people, but also to get access to information and create new knowledge in other fields like math or sciences (Michaud and McCoy, 2000; Flórez Aristizábal et al., 2017b). During the first five years of age, children should acquire their first language, for deaf children, it must be a sign language (Mellon et al., 2015) and this will allow them to become bilingual in a written language like English or Spanish but this is not an easy process since the strategies used with deaf children must di $\square$ er from those used with hearing children, taking into account that they cannot map sounds with letters and the structure of both languages (signed and written) are not the same, for instance, American Sign Language (ASL) which is the language used by deaf community in United 
States, is not English, they are two completely di $\square$ erent languages (Michaud and McCoy, 2000; Goldin-meadow and Mayberry, 2001). Some strategies, like storytelling, are used to engage children into learning a written language, due to stories make the literacy learning process meaningful as they can relate printed words with stories they enjoy. Another way to engage children into learning is through the inclusion of ICT in the classroom (Alsumait and Al-Musawi, 2013), but this has to be done carefully since technology can become a distraction. Unfortunately, there is not a clear guide for the development of tools aimed at deaf children to support literacy teaching, these tools should be designed taking into account the particular needs of the children and also the needs of the teachers to support their work. In order to achieve this goal, we have followed the literacy teaching process for deaf children at two educational institutions in Colombia and the purpose of this study is to transform the way storytelling is being used in the classroom to a new approach of collaborative interactive storytelling. Currently, storytelling has been used in these two institutions with existing stories of di $\square$ erent authors. The text that is part of the stories used, is the first contact children have with literacy learning, that is why the selection of the material must be adequate for their age, not just the story that is being told but also the text that is going to be part of the learning process. In Colombia, these institutions who work with children with some type of disability must face barriers to this

digital transformation, such barriers are:

Limited access to technology. Many institutions in Colombia still do not have access to Internet or they do it is restricted. Adjustment of the contents to the needs of each student. In other words, one of the biggest problems in Colombia is that education

is not actually inclusive in all the schools. For this reason, there are institutions or foundations that are created towards a group of children with particular needs. We can name some of the institutions that we have been working on: Institute for Blind and Deaf Children of Valle del Cauca (INCSVC) who works with children with hearing disabilities and children with visual disabilities. Institute Tobías Emanuel (ITE) who works with children with cognitive disabilities and the Institute of Special Therapy of Senses (ITES), who works with children with hearing disabilities and users of sign language.

Limited access to mobile devices, such as Tablets. Some institutions receive donations but some others do not have the oppor-tunity to have access to this kind of technology.

\subsection{Hypothesis}

The inclusion of ICT to transform storytelling into interactive storytelling can motivate and engage children into literacy learning and provide valuable data to educators in order to monitor the learning process.

\section{Case studies}

Three case studies were carried out in 2 di $\square$ erent institutions, one of them in Cali city and the other one in Popayán city. Consent forms were signed by the legally authorized representatives of the children in order to guarantee that all the information collected will be used only for research purposes and no sensitive or private information would be exposed, such as names or the faces of the children.

\subsection{Case study 1 (Storytelling at ITES)}

For this first case study, two sessions were carried out at the Institute of Special Therapy of Senses (ITES) (Cali, Colombia). The purpose of this case study is to involve children in the design of a set of cards with some drawings to create a story. The first session was done with a paper prototype of the story and the second one with printed and colorful cards based on suggestions given by students in the first session. For the design of this prototype used in the first session, the teacher agreed to do it with only one girl and thought that the story was suitable for the age of the children.

\subsection{Participants}

In this case study, children from ITES institution participated during two sessions. The first session involved children from the fifth grade and their ages range from 10 to 13 years old. The second session involved children from the third grade (9-11 years old). The reason to carry out the sessions with di $\square$ erent students was because children from the first session already knew the story behind the cards and the idea was to allow children to create a story on their own with no previous information about it. It is important to note that the work must be done according to the availability of teachers, so it makes it di $\square$ cult to carry out consecutive sessions with the same students.

\subsubsection{Material}

Paper prototype of a set of cards with images to create a story.

\subsubsection{Session 1}

The designer of this study created a story with 8 cards as a paper prototype and each card had a pre-defined position for that particular story (See Fig.1). Each card had an image with no color, they were drawn with just a pencil on a piece of paper. The story has 2 characters, a boy (Kevin) and a creature from another planet (Koos). The context of the story is Halloween. The description of each card is given below: 

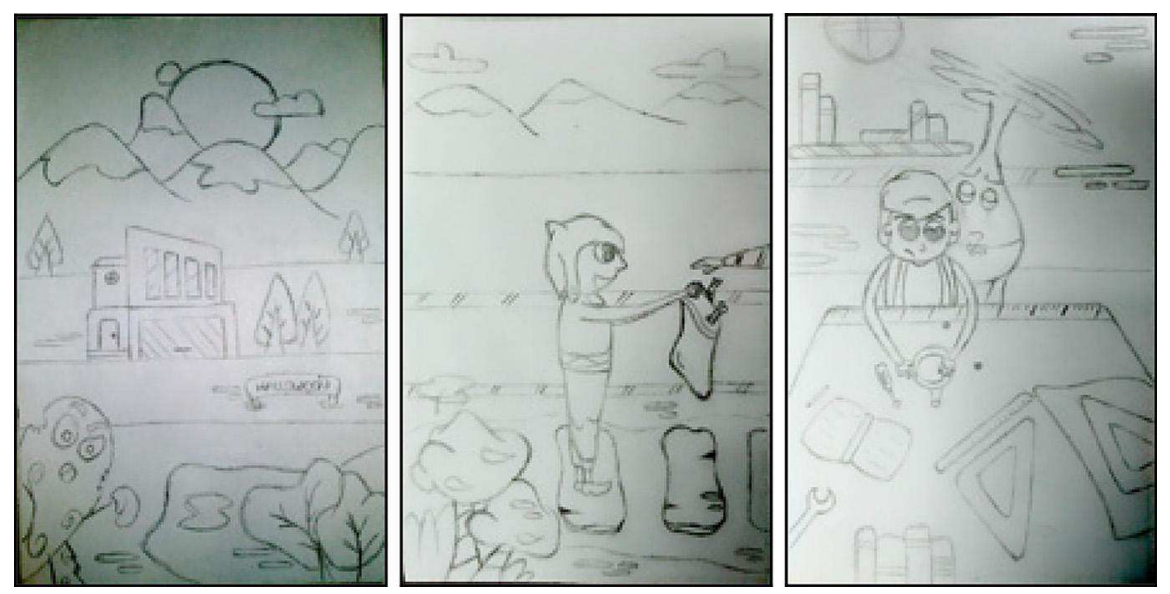

Fig. 1. Paper prototype of the cards for the first story.

1. This is the cover of the story.

2. Kevin is preparing his Halloween costume

3. Kevin puts his costume on

4. Kevin goes out to get some candies

5. A strange creature (Koos) appears in front of Kevin with a broken device

6. Kevin is helping Koos to repair the device

7. Kevin returns the repaired device to Koos

8. Koos leaves really happy and Kevin feels proud of himself.

Children for this first session are in fifth grade (10-13 years old). The objective of this first case study was to get feedback about the design of the cards, the characters and the situations of the story, which is why the case study was carried out with only one child for a period of $30 \mathrm{~min}$. One girl was selected for this purpose, she is 12 years old and she seated in the middle of the classroom with a set of scrambled cards. By using sign language, the teacher explained to the girl, and the rest of the group, that the student should arrange the cards to create a story. It was really important to tell the child that there were no right or wrong positions of the cards and that she was supposed to create a story of her own (See Fig.2).

Something curious about this first session, is that the rest of the children who were seating, started to stand up around the girl and wanted to collaborate giving opinions about the specific position of certain cards. The girl selected to do this activity, instead of rejecting the opinions of her classmates, she started an exchange of ideas in sign language which in the end, gave as a result a similar story to the one created by the designer (See Fig. 3).

Once the cards were arranged, we asked the girl to tell the story she and her classmates created. She did it using sign language and her teacher was our interpreter. From the story told by the student, we identified some mistakes in the design of the cards, one of them was that the expressions of the characters we wanted to show were not always right, for instance, an expression of surprise was confused with fear. This is really important when working with deaf children since their main input channel is visual and facial gestures are part of their mother language, so they pay special attention to the little details, which is why working with them during the design of a system is really helpful. After this part of the activity, we told the children the story we had in mind when we created

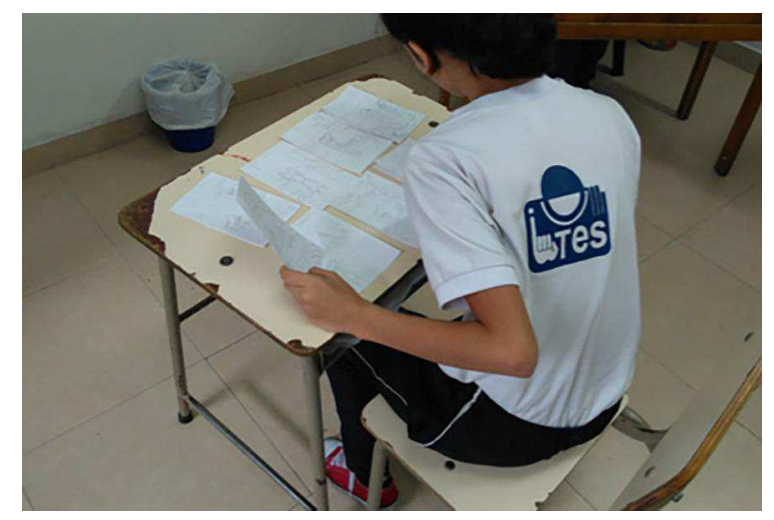

Fig. 2. Girl arranging the cards to create a story. 


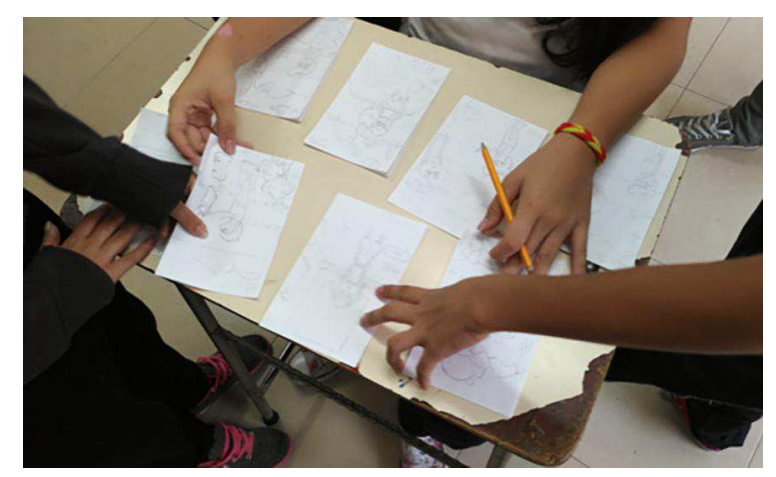

Fig. 3. Children collaborating to create a story.

the cards. The teacher, again, played the role of interpreter for the children.

When the activity ended, we asked the children to give their opinions about the design of each card. In general, they had a good impression of the cards and they really liked the drawings. One obvious improvement they suggested was to use colors for the cards so they could identify more easily what a card is supposed to tell. Another issue with the paper prototype of the cards was that some elements of the story were not easy to understand, for instance, some children thought that Kevin was making bread (kneading dough), when he actually was preparing his costume and some others did not realize that Koos' device was broken. All issues found during this first session are mainly due to the lack of colors in the prototype and some of the key elements of the images were not accurately drawn.

\subsubsection{Session 2}

For this second session, the same story and set of cards was used but this time, cards were designed and printed with colors. The designer was more careful when drawing facial expressions and little details like making Koos' non-functional device to actually look broken. We also decided to leave the first card (Cover) out of the activity since it could confuse the children about the position of the card (See Fig. 4).

We decided to carry out this session with di $\square$ erent children because the ones from the previous case study already knew what the story was about. Children from this session are a little bit younger ( 9 to 11 years old). The duration of this session was $1 \mathrm{~h}$ due to the number of participants (See Fig. 5).

3 sets of 7 cards were printed and there were 9 children in the classroom, so we divided the students into 3 groups of 3 children. The teacher explained the activity to the groups and we immediately noticed that 1 girl wanted to assume the leadership of her group, unfortunately, she did not take into account the suggestions of her classmates. In the other 2 groups, children worked together, but apparently they did not understand the activity at the beginning because they were trying to make the cards match like a puzzle.

Once all the groups finished organizing the cards, we asked them to tell us what their stories were about. At this point, we expected all children from the same group to tell the same story (See Fig. 6).

In the first group, 2 of the children described each card but it was not a story, the remaining child did tell the story he understood. In group number 2, they just described the images on each card. Something curious about group number 3 is that one girl arranged the cards and told her story, but the second girl, rearranged them according to what she believed was the right arrangement of the cards and told her own tale. The third child told his story with the same arrangement of the first girl.

Something we did not expect was that the teacher, who is also deaf, wanted to tell the story he understood. In this case, he told it with the cards arranged according to the story we thought from the beginning. Finally, another teacher who was playing the role of interpreter for us, told the real story for everyone Figs. 1-6

\subsubsection{Evaluation}

For this second session, we prepared an evaluation which was reviewed by one of the teachers of the institution, to let the children
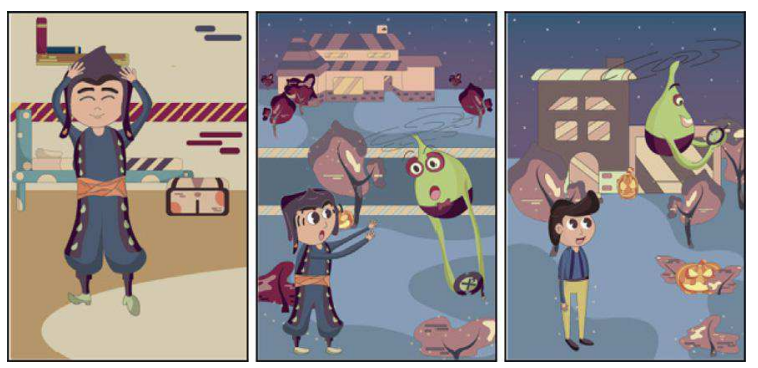

Fig. 4. Final design of printed cards for the first story. 


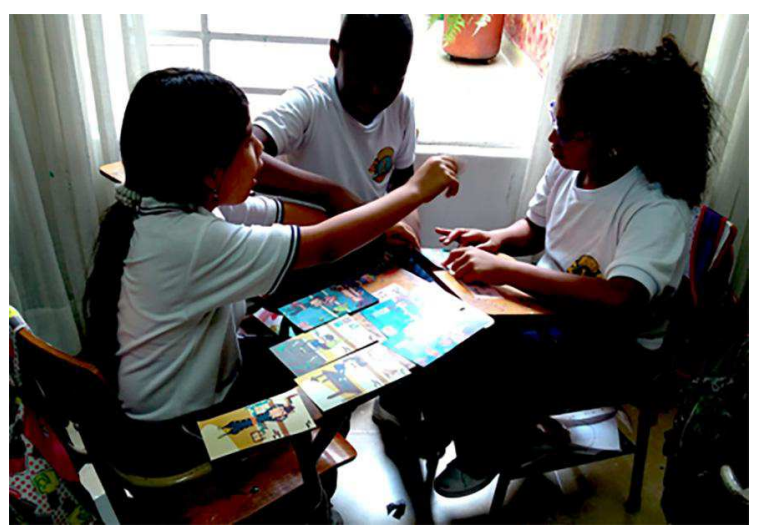

Fig. 5. Children working in groups with printed cards.

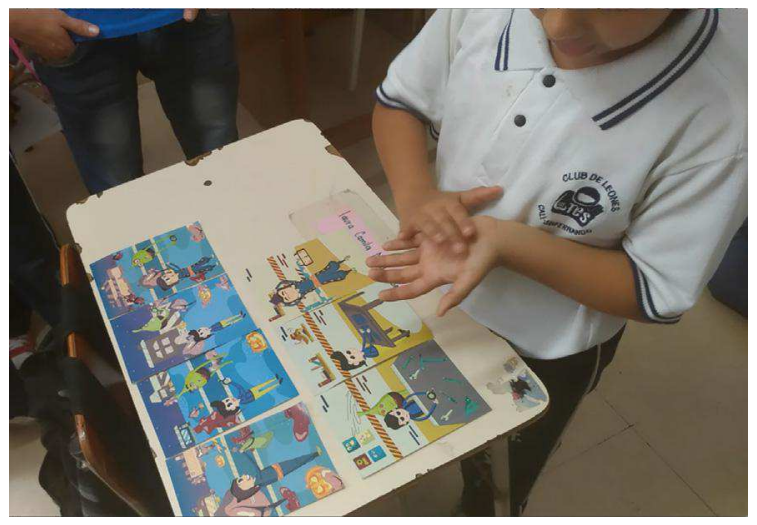

Fig. 6. Child explaining the story created in his group.

express their opinions about the cards and some aspects about the activity. To achieve this, four questions were asked:

1. Was the activity clear to you?

2. Did you have fun with the activity?

3. What do you think about the drawings in the cards?

4. Were the images in the cards easy to understand?

To answer the questions, we used a three-scale smileyometer which is a discrete Likert type scale composed by faces that show a di $\square$ erent expression from Awful (sad face) to Brilliant (happy face) (Read and MacFarlane, 2006). Fig. 7 shows the original version of the smileyometer.

We asked the children to draw one of the three emotions to express their opinions about each question (happy, neutral and sad face). (See Fig. 8).

\subsubsection{Results}

The evaluation was made with 7 out of 9 children since 2 of them did not understand the questions of the evaluation; according to the teacher, the level of sign language of these two children is lower than the rest of the group. Table 1 shows the answers of the

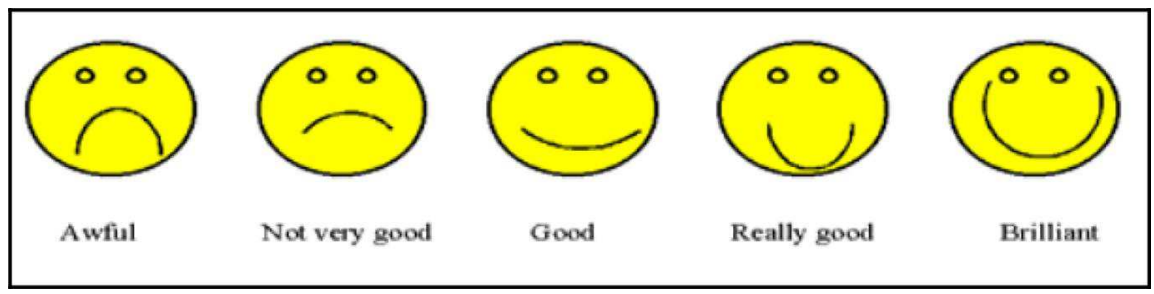

Fig. 7. Five-scale smileyometer (Read and MacFarlane, 2006). 


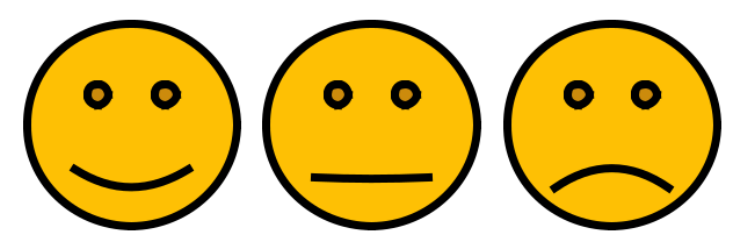

Fig. 8. Three-scale smileyometer.

Table 1

Results of first evaluation.

\begin{tabular}{lllll}
\hline Student & Q1 & Q2 & Q3 & Q4 \\
\hline S1 & H & H & H & H \\
S2 & H & H & H & H \\
S3 & H & H & H & H \\
S4 & H & S & H & H \\
S5 & H & H & H & H \\
S6 & H & H & H & H \\
S7 & H & H & H & \\
\hline
\end{tabular}

students, where their names are not given in the results, instead, they will be identified as S1, S2, S3, S4, S5, S6, S7. Q1 to Q4 are the four questions asked and H, N, S correspond to the possible answers (Happy, Neutral, Sad). (See Fig. 9).

The results show that children enjoyed creating their own stories with printed cards.

\subsection{Case study 2 (Storytelling at La Pamba)}

The purpose of this case study was to get information from children who study in di $\square$ erent conditions and contexts, for instance, these children from La Pamba have a group of specialists in every class (teacher, linguistic model, interpreter), di $\square$ erent from children at ITES where they only have the support of one teacher.

\subsubsection{Participants}

For this case study, four students ( 2 boys and 2 girls.) from the Educational Institution La Pamba (Popayán, Colombia) partici-pated during one session. Three of them ( 2 boys and 1 girl) are 14 years old, the other girl is 22 years old but her mental age is around 12 due to a late acquisition of a first language (sign language).

\subsubsection{Material}

Printed cards used in session 2 of the previous case study.

\subsubsection{Session}

This session was carried out at another school called La Pamba. Here, we had the support of the teacher, a deaf linguistic model, an interpreter and two undergraduate students. This session lasted $45 \mathrm{~min}$ due to a low number of students who participated. The same cards for the second session of the first case study were used and we decided to create two groups of 1 boy and 1 girl each. The teacher and the interpreter explained the activities to the students with a lot more detail than the teachers from ITES, giving examples and even mimicking the activity as they were giving the explanation, which gave students enough information to understand what they had to do in a collaborative way.

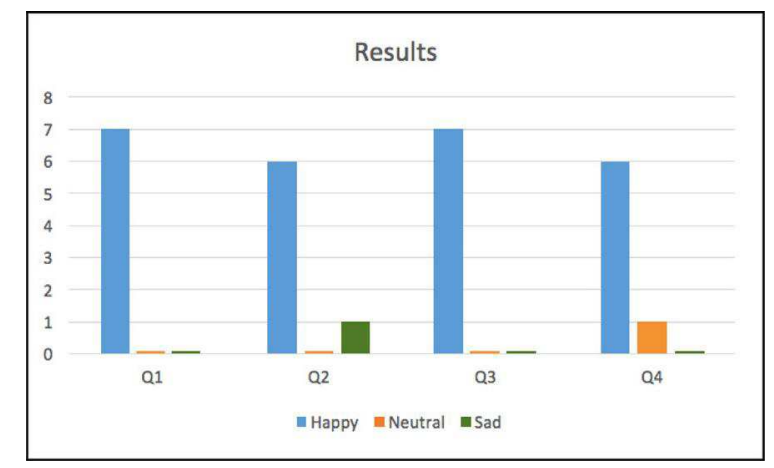

Fig. 9. Results of first evaluation. 
Table 2

Results of second evaluation.

\begin{tabular}{lllll}
\hline Student & Q1 & Q2 & Q3 & Q4 \\
\hline S1 & H & H & H & H \\
S2 & H & N & H & H \\
S3 & H & N & H & H \\
S4 & H & S & H & H \\
\hline
\end{tabular}

While the students were working together, we noticed that the boys were not very enthusiastic about the activity. Once the students arranged the cards, we asked them to tell us what the story was about. In this opportunity, we wanted them to tell it as a group and not individually, so they had to decide which part of the story was going to be told by each of them. The first group did a really good not just arranging the cards as close as the real story, but also using their imagination and working as a team. The second group did not work as a team mainly because the boy from this group did not feel comfortable doing the activity, the girl of this group, who is the 22-year-old student, was more enthusiastic and tried to make his classmate help her to create the story. In the end, they told a simpler and shorter story.

\subsubsection{Evaluation}

The same evaluation for the second session of the first case study was used with the same questions:

1. Was the activity clear to you?

2. Did you have fun with the activity?

3. What do you think about the drawings in the cards?

4. Were the images in the cards easy to understand?

The smileyometer from the previous case study was also used to answer the questions.

\subsubsection{Results}

Table 2 shows the answers of the students, where their names are not given in the results, instead, they will be identified as S1, S2, S3, S4. Q1 to Q4 are the four questions asked and H, N, S correspond to the possible answers (Happy, Neutral, Sad). (See Fig. 10).

These results show that children who are preadolescents may not find interesting these kind of activities as can be seen in the responses of question 2.

\subsection{Case study 3 (Card-based storytelling vs digital Storytelling)}

The purpose of this last case study was to compare how children interact with two di $\square$ erent approaches, one of them based on printed cards and the other one based on digital cards through a computer. The new story was designed based on recommendations given by the teachers who suggested to use a context of daily life for children.

\subsubsection{Participants}

For this case study, children from ITES participated during one session. These children are in fourth grade and their ages range from 10 to 14 years old.

\subsubsection{Material}

Printed cards used in previous case studies (Halloween story) and a software application for desktop computers with digital cards

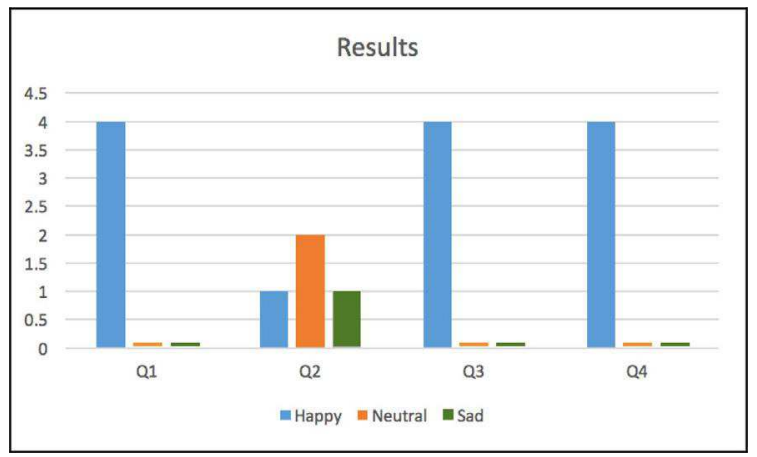

Fig. 10. Results of second evaluation 


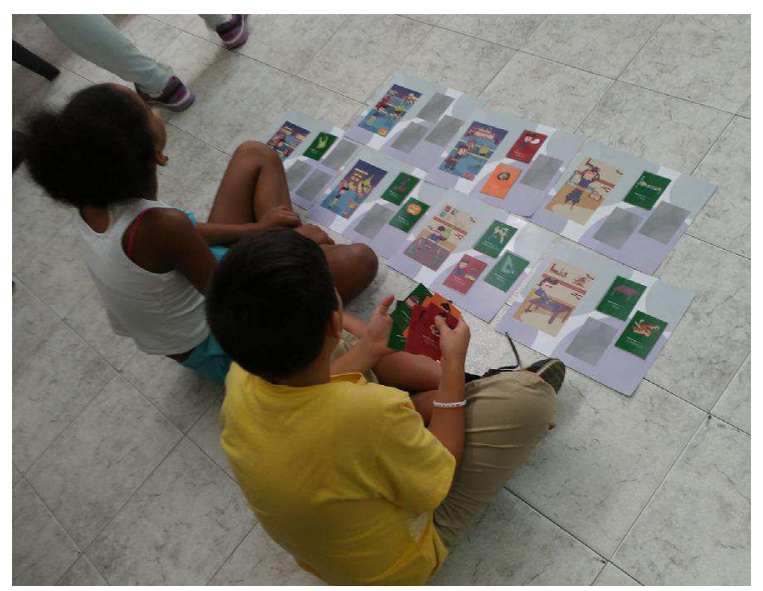

Fig. 11. Children working in pairs to arrange the physical cards.

and di $\square$ erent drawings (Biology class story) Figs. 8-10.

\subsubsection{Session}

In this session, six children were divided into three groups to work in pairs. The designer of the study created another story with seven cards, in this case, the cards were designed using colors and taking into account the suggestions and findings from previous case studies. This second story has one main character (Kevin). The context of the story is Biology class. The description of each card is given below:

1. Biology teacher is explaining about the lifecycle of plants.

2. Kevin plants a seed in a pot

3. Kevin is worried because his plant is not growing

4. A classmate tells Kevin that the plant needs water and sunlight

5. Kevin starts watering his plant and places it near a window with direct sunlight

6. Kevin's plant starts to grow

7. Kevin shows his results and a beautiful plant in front of the class.

For this session, two di $\square$ erent activities were carried out with two sets of cards (Halloween and Biology class) for a period of $1 \mathrm{~h}$ and the reason to use both stories is because we did not want children to create the same story in both activities taking into account that one of them was with printed cards and the other one with digital cards. For the first activity, the children worked in pairs using the cards from the previous case studies (Halloween) to create a story as can be seen in Fig. 11. It is important to notice that before this activity, children were not enthusiastic about it, they did not want to participate because the activity was not attractive to them. Once they arranged the cards, they were asked to tell the story using sign language while the teacher played the role of interpreter to us.

The second activity consisted of a new approach for these children and the teachers, in this occasion, the students had the opportunity to do the same activity of creating a story by arranging a new set of scrambled digital cards with the second story (biology class) using a computer through an interactive software application developed with Processing IDE (Fig. 12). The application allowed children to type their names and after that, they could drag and drop each card in a particular space according to the story

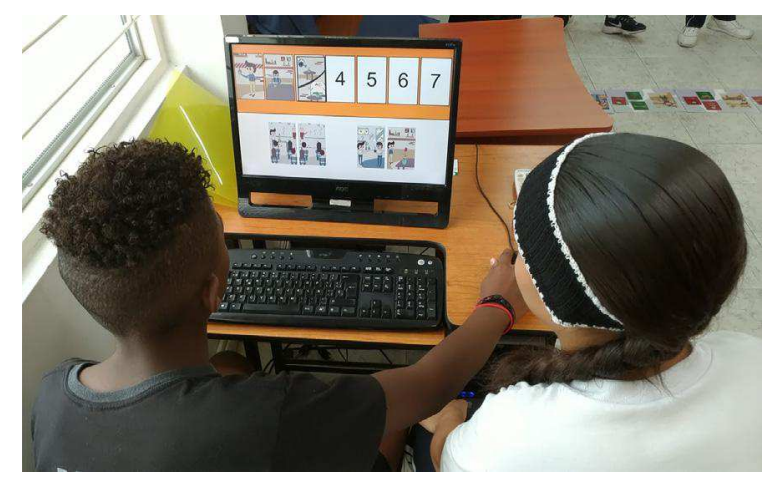

Fig. 12. Children working in pairs to arrange the digital cards. 


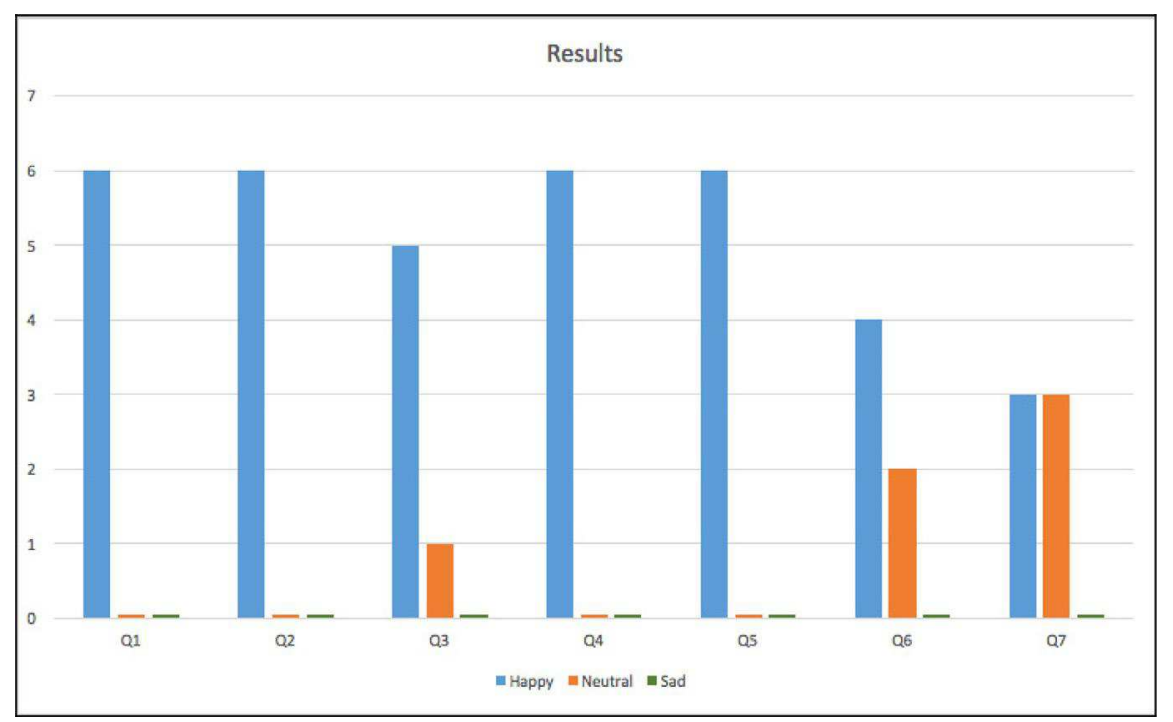

Fig. 13. Results of third evaluation.

they wanted to create. When the last card is placed in the last available position, the application rewards the student with a trophy, a congratulation message with his/her name and the time spent creating the story. We decided to include the name and the reward to apply two positive interdependences, which are Identity and Celebration/Reward, the latter is also a game mechanic that can be found in all video games and is necessary in order to keep the player/learner motivated.

Once the students used the software application, their motivation increased to the point that they did not want to leave the classroom waiting for another chance to use the software, which confirms that ICTs are a valuable resource to engage children into learning. At the end of both activities, students were asked to answer a short survey about their experience. The questions and the results are shown below Fig. 13.

For this case study, we included additional pictograms with vocabulary related to the cards used by the children. The idea was first to make sure if the children knew this vocabulary and in case they did not, it was taught first by showing the corresponding sign of the words and then they were asked to associate each word with a particular card (scene) of the story. From this moment on, the teacher starts the process of teaching literacy from the stories created by the students and the selected vocabulary which was chosen based on current children's literacy knowledge and age.

\subsubsection{Evaluation}

The questions asked to the children about the use of the cards and the app are:

1. How did you feel using the cards?

2. How did you feel using the app on the computer?

3. The activities were clear to you?

4. Did you have fun using the cards?

5. Did you have fun using the app on the computer?

6. What do you think about the drawings?

7. The drawings were easy to understand?

8. Did you like to work with your classmate? Why?

9. Next time, do you prefer to use the cards or the app on the computer?

10. Why would you prefer to use the cards/app?

The smileyometer from the previous case studies was also used to answer most of the questions.

\subsubsection{Results}

The results of the survey are shown in Table 3; once again, their names are not given in the results, instead, they will be identified as S1, S2, S3, S4, S5 and S6. Q1 to Q7 are the first seven questions asked and H, N, S correspond to the possible answers (Happy, Neutral, Sad) (See Fig. 13). Answers to Q8, Q9 and Q10 are shown in Table 4.

This results show that images in the cards must be improved since the drawings are not completely easy to understand according to children's responses. The digital drawings could have been more di $\square$ cult to understand since the size of the images is restricted by the size of the computer's screen. 
Table 3

Results of third evaluation (part 1).

\begin{tabular}{|c|c|c|c|c|c|c|c|}
\hline Student & Q1 & Q2 & Q3 & Q4 & Q5 & Q6 & Q7 \\
\hline S1 & $\mathrm{H}$ & $\mathrm{H}$ & $\mathrm{H}$ & $\mathrm{H}$ & $\mathrm{H}$ & $\mathrm{H}$ & $\mathrm{H}$ \\
\hline S2 & $\mathrm{H}$ & $\mathrm{H}$ & $\mathrm{H}$ & $\mathrm{H}$ & $\mathrm{H}$ & $\mathrm{N}$ & $\mathrm{N}$ \\
\hline S3 & $\mathrm{H}$ & $\mathrm{H}$ & $\mathrm{H}$ & $\mathrm{H}$ & $\mathrm{H}$ & $\mathrm{N}$ & $\mathrm{N}$ \\
\hline S4 & $\mathrm{H}$ & $\mathrm{H}$ & $\mathrm{N}$ & $\mathrm{H}$ & $\mathrm{H}$ & $\mathrm{H}$ & $\mathrm{H}$ \\
\hline S5 & $\mathrm{H}$ & $\mathrm{H}$ & $\mathrm{H}$ & $\mathrm{H}$ & $\mathrm{H}$ & $\mathrm{H}$ & $\mathrm{H}$ \\
\hline S6 & $\mathrm{H}$ & $\mathrm{H}$ & $\mathrm{H}$ & $\mathrm{H}$ & $\mathrm{H}$ & $\mathrm{H}$ & $\mathrm{N}$ \\
\hline
\end{tabular}

Table 4

Results of third evaluation (part 2).

\begin{tabular}{|c|c|c|c|}
\hline Student & 8 & Q9 & Q10 \\
\hline S1 & $\begin{array}{l}\text { Yes, I liked to work with my classmate because we had the chance to } \\
\text { share and choose the cards }\end{array}$ & $\begin{array}{l}\text { Next time, I prefer to use the app on the } \\
\text { computer }\end{array}$ & $\begin{array}{l}\text { Because I like to use the } \\
\text { computer }\end{array}$ \\
\hline S2 & $\begin{array}{l}\text { Yes, I liked to work with my classmate because he helped me and } \\
\text { joined me }\end{array}$ & $\begin{array}{l}\text { Next time, I prefer to use the app on the } \\
\text { computer }\end{array}$ & Because I had much more fun \\
\hline S3 & Yes, I liked to work with my classmate & Next time, I prefer to use the computer & The student did not answer \\
\hline S4 & $\begin{array}{l}\text { Yes, I liked to work with her because we were playing, exchanging } \\
\text { and choosing the right place of the cards }\end{array}$ & Next time, I prefer to use the computer & $\begin{array}{l}\text { Because I liked the images and it } \\
\text { was fun }\end{array}$ \\
\hline S5 & $\begin{array}{l}\text { Yes, I liked to work with him because we shared the cards during the } \\
\text { process, we played and it was fun }\end{array}$ & Next time, I prefer to use the app & $\begin{array}{l}\text { Because I liked it and it was } \\
\text { interesting }\end{array}$ \\
\hline S6 & I felt good, the activity was nice. & $\begin{array}{l}\text { Next time I would like to use both (the } \\
\text { cards and the app). }\end{array}$ & I liked both activities. \\
\hline
\end{tabular}

\section{Discussion}

Each of the 3 case studies gave us relevant information to be taken into account in the design of interactive storytelling. First of all, the paper prototype of the cards can give some insights about the elements to be carefully designed in the images to be part of the story. It is also important to have children's opinion from the beginning since they can give relevant information about the drawings, especially when emotions of the characters play an important role in the story, for instance, a surprise expression was confused with fear. One of the suggestions given by the teachers was to use stories that are related to the children's daily living, avoiding strange characters like Koos (first set of cards), at least with children that are in the first stages of a written language acquisition since it can be di $\square$ cult to explain words that do not exist or situations that are not real. Assigning a sign name to the characters before doing the activity is also suggested so the children may refer to them by their sign when telling the story.

Age is an important fact when working with children since they can find this kind of activities boring or childish when they are becoming teenagers, that is why it is important to know about the potential future users, not just their chronological age but also their mental age, as we noticed in one of the case studies, a girl who is 21 years old was excited about the activity due to her mental age is 12 .

The activities to be carried out in a collaborative way must also be carefully designed because the result may not be the desired one just by making groups and tell them to work together. Positive interdependences play an important role when we want children to collaborate in order to achieve a common goal. When working in groups, the number of children in an activity must be adequate to avoid conflicts among members of the group, as we evidenced in the second case study, groups of three children were too big to create a story with just seven cards, so we did not see a common agreement among children of some groups. On the other hand, working in pairs resulted in a better group work and consensus of the groups.

Children's motivation increased when technology was part of the activity, for our third case study, children had to take turns to use the computer because only one of the computers available in the classroom had Internet access and this was necessary to install a Java update needed for the software to work, this limited the activity to be used individually, but even though children were told to work on their own, they could not resist to work with their respective classmate from the previous activity.

The results of the three evaluations show that the storytelling activities were attractive to children, only two children from the second evaluation felt this activity was not for them due to their age. They also show that involving students and teachers in the design process, was necessary to create a solution that is both, usable and accessible, with the limited available resources in both institutions. The developed tool complements the current teaching strategies used and meets the needs of the teachers and the students.

This study coincides with others like (Malzkuhn and Herzig, 2013) and (Alsumait et al., 2015) where it is demonstrated how technology can improve a storytelling strategy for literacy teaching by engaging and motivating children. To the best of our knowledge, and based on literature review and teacher's requests, there is no other digital storytelling approach that can actually be used as part of their teaching process, either because the educational institutions don't have the necessary technological resources or because some digital resources are not meant to be used for teaching Spanish to deaf children.

Our proposal can be easily adapted for literacy teaching in any language for both, hearing and Deaf children. Even though the 
results of this study are positive, there is still more research to do about the assessment of children's learning after using this approach in a regular basis.

The results of this study will be used by teachers from both institutions to improve their teaching strategies and also as part of the validation process of a framework that is being developed for the design of interactive collaborative tools to support literacy teaching to deaf children through storytelling.

\section{Conclusions and further work}

Teachers from the institutions we worked with, expressed their joy about this study because they mentioned the traditional way to use storytelling with existing stories was limiting their work since it is not easy to find new books with di $\square$ erent stories, besides, it implies to keep buying this material which is not possible due to the lack of resources in the institutions. With this new approach, they can create all kind of stories through children's imagination. They also regret that there are not applications to be used in the institution, either because some of them are licensed or do not work in the old computers they have, that is why they requested a copy of the app which will be updated to include more game and learning mechanics, as well as more positive interdependences.

The use of technology can be a game changer in the classroom, it was amazing to see how the same activity changed the mood of the students just by modifying the way to do it, from physical cards to digital ones. The use of technology as a resource in the classroom allows to collect data instantly and reward students for their achievements as we did in the third case study. Although, these strategies where ICTs are involved, may have an undesired result if they, or their content, are not used properly. In our third case study, we showed the student the time taken to finish the story, unfortunately, students perceived this as a time to be beaten, so they continued using the tool, but they were not thinking about creating a story, instead, they were trying to order the cards as fast as possible to reduce the time stamp. This distorted the purpose of the activity which was to think about a story, so proper game and learning mechanics must be chosen during the design of a system that is supposed to support the teaching/learning processes.

It is important to mention that it is necessary to structure activities to convey a real collaboration, due to just making a group of people work around a task does not guarantee a real collaboration and participation. As further work we are going to model activities in a way where aspects like positive interdependence, equal participation and individual accountability (fundamental aspects of collaborative learning processes) could be integrated in the storytelling process.

It is also important to highlight that paper prototyping is an inexpensive and easy way to collect useful information for a later digital design. The first two case studies did not make use of technology and it was a funny and interesting way to engage children into storytelling, on the other hand, the third case study did involve the use of technology and the results showed that the information gathered in case studies 1 and 2 was necessary to achieve a usable, accessible and engaging software-based application for interactive storytelling.

The results of this study show that an interactive storytelling activity mediated by computers may engage and motivate children in literacy learning. The process carried out in this study (from paper prototype to high-fidelity prototype) is recommended to guarantee a good design as children are involved during the whole process.

\section{References}

Acer for Education, A., 2017. 5 Ways Digital Transformation impacts on classrooms [WWW Document]. http://eu-acerforeducation.acer.com/education-trends/5-ways-digitaltransformation-impacts-on-classrooms/ (accessed 5.22.18).

Alsumait, A., Al-Musawi, Z.S., 2013. Creative and innovative e-learning using interactive storytelling. Int. J. Pervasive Comput. Commun. 9, 209-226. https://doi.org/ 10.1108/IJPCC-07-2013-0016.

Alsumait, A., Faisal, M., Banian, S., 2015. Improving Literacy for Deaf Arab Children Using Interactive Storytelling. In: IiWAS '15 Proceedings of the 17th International Conference on Information Integration and Web-Based Applications \& Services. p. 5.

Arias Ortiz, E., Cristia, J., 2014. El BID y la tecnología para mejorar el El BID y la tecnología para mejorar el aprendizaje : ¿ Cómo promover programas efectivos ? Banco Interamericano de Desarrollo 75.

Baller, S., Dutta, S., Lanvin, B., 2016. The Global Information Technology Report 2016: Innovating in the Digital Economy, WEF. Insead, Geneva.

Bazzaza, M.W., Salah, K., 2015. Using the Cloud to Teach Computer Networks. In: Proceedings - 2015 IEEE/ACM 8th International Conference on Utility and Cloud Computing, UCC 2015 310-314. https://doi.org/10.1109/UCC.2015.49.

Bradley, J., Loucks, J., Macaulay, J., Noronha, A., Wade, M., 2015. In: Digital Vortex: How Digital Disruption is Redifining Industries. Global Center for Digital Business Transformation, pp. 1-24.

Burd, B., Barker, L., Divitini, M., Perez, F.A.F., Russell, I., Siever, B., Tudor, L., 2017. Courses, Content, and Tools for Internet of Things in Computer Science Education. In: Proceedings of the 2017 ITiCSE Conference on Working Group Reports - ITiCSE-WGR '17 125-139. https://doi.org/10.1145/3174781.3174788.

Burke, Q., Kafai, Y.B., 2010. Programming \& Storytelling: Opportunities for Learning About Coding \& Composition. In: Proceedings of the 9th International Conference on Interaction Design and Children - IDC '10 348. https://doi.org/10.1145/1810543.1810611.

Chiong, C., Shuler, C., 2010. Learning: Is there an app for that? Investigations of young children's usage and learning with mobile devices and apps. The Joan Ganz Cooney Center 34. https://doi.org/10.4212/cjhp.v64i4.1054.

Flórez Aristizábal, L., Cano, S., Collazos, C., 2017a. Using storytelling to support the education of deaf children: a systematic literature review. In: Marcus, A., Wang, W. (Eds.), Design, User Experience, and Usability: Understanding Users and Contexts: 6th International Conference, DUXU 2017, Held as Part of HCI International 2017, Vancouver, BC, Canada, July 9-14, 2017, Proceedings, Part III. Springer International Publishing, Cham, pp. 371-382.

Flórez Aristizábal, L., Cano, S., Vesga Parra, L.del S., Collazos, C.A., 2017b. Towards the design of interactive storytelling to support literacy teaching for deaf children. 
In: Guerrero-García, J., González, J.M., Muñoz, J., Collazos, C.A. (Eds.), HCI for Children with Disabilities. Springer International Publishing, pp. 115-126.

Garzotto, F., Paolini, P., Sabiescu, A., 2010. Interactive storytelling for children. In: Proceedings of the 9th International Conference on Interaction Design and Children IDC 10. Barcelona, pp. 356-359. https://doi.org/10.1145/1810543.1810613.

Goldin-meadow, S., Mayberry, R.I., 2001. How do profoundly deaf children learn to read? Learn. Disabilities Res. Pract. 16, 222-229. https://doi.org/10.1111/0938-8982.00022.

Guttman, C., 2003. Education in and for the Information Society 1-84.

Malzkuhn, M., Herzig, M., 2013. Bilingual storybook app designed for deaf children based on research principles. Interact. Des. Children 499-502

Mascheroni, G., Ólafsson, K., 2014. Net Children Go Mobile. Risks and Opportunities, Second ed. Educatt.

Mellon, N.K., Niparko, J.K., Rathmann, C., Mathur, G., Humphries, T., Napoli, D.J., Handley, T., Scambler, S., Lantos, J.D., 2015. Should all deaf children learn sign language? Pediatrics 136, 170-176. https://doi.org/10.1542/peds.2014-1632.

Michaud, L., McCoy, K., 2000. An intelligent tutoring system for deaf learners of written English. In: Proceedings of the Fourth International ACM Conference on Assistive Technologies. Arlington, pp. 92-100. https://doi.org/10.1145/354324.354348.

Moreno de León, T.A., Rangel, L., De León, E., 2016. Promoviendo el desarrollo de la competencia lectora a través de cuentos con imágenes sin palabras en preescolar. Rev. Int. Educ. Preescolar Infantil 2, 49-64.

Oh, T. (Tom), Chung, S., Lunt, B., McMahon, R., Rutherfoord, R., 2017. The Roles of IT Education in IoT and Data Analytics. In: Proceedings of the 18th Annual Conference on Information Technology Education - SIGITE '17 39-40. https://doi.org/10.1145/3125659.3125674.

Peix Cruz, S., 2014. Carambuco : cuentos y actividades en lengua de signos. Bol. Asoc. Andaluza Bibliotec. 50-59.

Pérez Molina, D., Pérez Molina, A., Sánchez Serra, R., 2013. El cuento como recurso educativo. 3C Empresa.

Read, J.C., MacFarlane, S., 2006. Using the fun toolkit and other survey methods to gather opinions in child computer interaction. In: Proceeding of the 2006 conference on Interaction design and children - IDC '06 81-88. https://doi.org/10.1145/1139073.1139096.

Reyes Torres, A., Pich Ponce, E., García Pastor, M.D., 2012. Digital Storytelling as a Pedagogical Tool within a Didactic Sequence in Foreign Language Teaching El relato digital como herramienta pedagógica en la enseñanza de lenguas extranjeras a través del uso de la secuencia didáctica. Digital Educ. Rev. 1-18.

Social Computing Research Group, 2005. Understanding computer mediated social experience: implications for CSCL. CSCL '05 Proceedings of th 2005 conference on Computer support for collaborative learning: learning 2005: the next 10 years! 617-621.

UNESCO, 2013. Enfoques Estratégicos Sobre Tics en Educación en América Latina y el Caribe, Enfoque Estratégico Sobre Tics. En Educación En América Latina Y El Caribe.

UNICEF, 2017. El Estado Mundial de la Infancia: Niños en un Mundo Digital. New York.

Valderrama Bahamóndez, E. del C., Schmidt, A., 2010. A survey to assess the potential of mobile phones as a learning platform for panama. Proceedings of the 28th of the international conference extended abstracts on Human factors in computing systems - CHI EA '10 3667. https://doi.org/10.1145/1753846.1754036. 